\title{
Palmarosa Oil
}

National Cancer Institute

\section{Source}

National Cancer Institute. Palmarosa Oil. NCI Thesaurus. Code C107341.

The essential oil of Cymbopogon martini. Palmarosa oil is used in treatments for the skin, nervous, and digestive systems. 